\title{
The Effect of Soil Acidity Factors on Crop Yields IX. Taniers ${ }^{1,2}$
}

\author{
José Vicente-Chandler, Fernando Abruña, José Badillo Feliciano and \\ José A. Rodriguez-García
}

\begin{abstract}
Yield of taniers on a Corozal clay (Ultisol) decreased with increasing soil acidity from $16.3 \mathrm{t} /$ ha at $\mathrm{pH} 5.0$ with $12 \%$ saturation of the CEC with $\mathrm{Al}$, to 4.2 t/ha at $\mathrm{pH} 4.2$ and $70 \% \mathrm{Al}$ saturation. Similar results were obtained on Corozal clay subsoil. Much lower yields were produced on Coto clay (Oxisol). These yields were lowered only at the highest acidity level, $\mathrm{pH} 4.5$, and $34 \%$ Al saturation of the soil CEC. Foliar composition of the taniers was not affected by soil acidity, except that the $\mathrm{Ca}$ content was appreciably less at the highest level of acidity on the Corozal soil and subsoil. For all soils combined, $\mathrm{pH}$ and percent Al saturation of the soil CEC correlated very closely with yields. Overall yields were close to maximum when the soil had a pH of 5.2 and no exchangeable Al.
\end{abstract}

\section{INTRODUCTION}

Taniers or cocoyams (Xanthosoma sp.) are an important source of carbohydrates throughout the humid tropics. They can produce over 20 $\mathrm{t}$ of edible tubers/ha and a similar amount of corms which can be used for feeding pigs (11).

Research information on taniers is generally limited to cultural practices $(6,9,10,12,13)$, but there is very little information on their response to liming. Abruña et al. (1) found that taniers did not respond to liming in two Ultisols with $\mathrm{pH}$ of 5.0 and 5.3.

This paper presents the results of a study to determine the effect of soil acidity factors on yields and foliar composition of taniers growing on two Ultisols and one Oxisol.

\section{MATERIALS AND METHODS}

The experiments were conducted on a Corozal clay soil and subsoil (Aquic Tropudults) and on a Coto sandy clay (Tropeptic Haplorthox). There were $304 \times 4$-m plots at each of the Corozal sites and 40 on the Coto soil. All plots were surrounded by ditches to prevent runoff from one plot to another and were arranged in complete randomized blocks.

${ }^{1}$ Manuscript submitted to Editorial Board September 30, 1982.

${ }^{2}$ This paper covers work carried out cooperatively between ARS, USA and the Agricultural Experiment Station, College of Agricultural Sciences, Mayagüez Campus, University of Puerto Rico.

${ }^{3}$ Soil Scientists, ARS-US Department of Agriculture; Agronomist and Assistant Agronomist, Agricultural Experiment Station, College of Agricultural Sciences, Mayagüez Campus, University of Puerto Rico, Río Piedras, P.R. 
The plots varied widely in soil acidity because of differences in rates of lime applied during previous years.

All plots. were planted to the Morada variety of taniers with corm sections weighing about $100 \mathrm{~g}$ each at $.6 \times .6 \mathrm{~m}$. At planting and $6 \mathrm{mo}$ later, all plots received $500 \mathrm{~kg} / \mathrm{ha}$ of a 10-10-10 fertilizer with $30 \mathrm{~kg} / \mathrm{t}$ of a minor element mixture containing $6 \% \mathrm{Mg}, 7.7 \% \mathrm{Mn}, 4.8 \% \mathrm{Cu}, 7 \% \mathrm{Fe}$, $8 \% \mathrm{Zn}$ and $2.5 \% \mathrm{~B}$. The plots were sprinkle irrigated at the rate of 50 $\mathrm{mm}$ weekly during dry periods and were harvested 1 year after planting.

Mature-active leaves were taken from plants in the center row of each plot $8 \mathrm{mo}$ after planting, washed with distilled water, dried at $70^{\circ} \mathrm{C}$, ground, and analyzed after wet digestion for $\mathrm{P}$, colorimetrically as molibdate (7); for $\mathrm{K}$, by flame photometry; for $\mathrm{Mn}$, colorimetrically as permanganate after oxidation with $\mathrm{KIO}_{4}$; and for $\mathrm{Ca}+\mathrm{Mg}$, by the Versenate method (4). Nitrogen was determined in a separate sample by the Kjeldahl method.

The soil in all plots was sampled about 4 mo after planting by 10 borings from 0 - to $15-\mathrm{cm}$ depths in each plot. The samples were air dried and passed through a 20 -mesh screen. Exchangeable $\mathrm{Ca}, \mathrm{Mg}, \mathrm{K}$, and $\mathrm{Mn}$ were extracted with neutral $\mathrm{N} \mathrm{NH}_{4} \mathrm{OAc}$. Potassium, $\mathrm{Ca}+\mathrm{Mg}$, and $\mathrm{Mn}$ were determined as for the leaf samples. Exchangeable Al was extracted by $N \mathrm{KCl}$ and determined by the double titration method (8). The Al saturation percentage of the effective CEC of the soil was calculated by dividing the exchangeable $\mathrm{Al}$ by the sum of exchangeable $\mathrm{Ca}, \mathrm{Mg}, \mathrm{K}, \mathrm{Al}$, and $\mathrm{H}$ (5). Soil $\mathrm{pH}$ was measured with a glass electrode for 1:1.5 mixtures of soil and water.

For statistical comparisons of the yield data, plots were grouped into Al saturation ranges of $10 \%$, with 0 content as a separate category. The effect of various soil acidity factors were related to yield through regression analyses.

\section{RESULTS AND DISCUSSION}

\section{COROZAL CLAY SOIL}

Taniers yield was not affected until soil pH dropped below 4.8 with $25 \% \mathrm{Al}$ saturation of the CEC (table 1), decreasing further to only about $25 \%$ of maximum at $\mathrm{pH} 4.2$ with $78 \% \mathrm{Al}$ saturation.

Taniers are relatively tolerant to high soil acidity. At $50 \% \mathrm{Al}$ saturation of the soil, taniers, yams and cassava produced, respectively, about $55 \%$, $19 \%$ and nearly $100 \%$ of their maximum $(2,3)$.

Leaf composition was not appreciably affected by soil acidity, except that the $\mathrm{Ca}$ content dropped when $\mathrm{pH}$ decreased from 4.6 to 4.2.

Regression analysis showed that all soil acidity factors correlated with yields at the .01 level (table 2). Exchangeable $\mathrm{Ca}+\mathrm{Mg}$ contents explained 
TABLE 1.-Effect of soil acidity factors on yields and foliar composition of taniers grown on two Ultisols and one Oxisol

\begin{tabular}{|c|c|c|c|c|c|c|c|c|c|c|c|c|}
\hline \multicolumn{5}{|c|}{ Soil acidity factors } & \multicolumn{2}{|c|}{ Yield } & \multicolumn{6}{|c|}{ Contents in leaves } \\
\hline $\mathrm{pH}$ & $\begin{array}{l}\text { Exch. } \\
\mathrm{Al}\end{array}$ & $\begin{array}{c}\text { Exchangeable } \\
\mathrm{Ca}+\mathrm{Mg}\end{array}$ & $\begin{array}{l}\text { Al satura- } \\
\text { tion of } \\
\text { CEC }\end{array}$ & $\begin{array}{c}\text { Exch. Al } \\
\text { Exch. base }\end{array}$ & Tubers & Corms & $\mathrm{N}$ & P & $\mathrm{K}$ & $\mathrm{Ca}$ & $\mathrm{Mg}$ & $\mathrm{Mn}$ \\
\hline & $m e / 100 \mathrm{~g}$ & $m e / 100 \mathrm{~g}$ & $\%$ & & \multicolumn{2}{|c|}{ t/ha } & \multicolumn{6}{|c|}{$\%$} \\
\hline \multicolumn{13}{|c|}{ Corozal clay soil } \\
\hline 5.80 & 0 & 13.46 & 0 & 0 & $16.3 \mathrm{a}^{1}$ & 19.1 & 3.07 & .23 & 2.65 & 1.25 & .56 & 208 \\
\hline 5.00 & 1.36 & 9.75 & 12 & .14 & $16.3 \mathrm{a}$ & 18.9 & 3.06 & .22 & 2.78 & 1.18 & .51 & 144 \\
\hline 4.80 & 3.17 & 9.24 & 25 & .33 & $13.2 \mathrm{a}$ & 12.1 & 3.06 & .23 & 2.83 & 1.22 & .46 & 205 \\
\hline 4.70 & 4.01 & 7.25 & 35 & .55 & $8.2 \mathrm{~b}$ & 8.9 & 3.09 & .22 & 2.61 & 1.18 & .48 & 230 \\
\hline 4.60 & 6.12 & 5.89 & 50 & 1.06 & $9.2 \mathrm{~b}$ & 9.7 & 3.11 & .22 & 2.79 & 1.21 & .48 & 176 \\
\hline 4.40 & 8.12 & 3.82 & 67 & 2.11 & $7.0 \mathrm{bc}$ & 8.2 & 2.96 & .23 & 2.53 & 1.08 & .54 & 174 \\
\hline 4.20 & 10.80 & 2.90 & 78 & 3.62 & $4.2 \mathrm{c}$ & 4.7 & 2.95 & .22 & 2.56 & 1.00 & .43 & 200 \\
\hline \multicolumn{13}{|c|}{ Corozal clay subsoil } \\
\hline 5.40 & 0 & 13.58 & 0 & 0 & $16.0 \mathrm{a}$ & 13.3 & 3.06 & .23 & 2.59 & 1.21 & .55 & 153 \\
\hline 5.00 & .85 & 9.06 & 7 & .07 & $16.0 \mathrm{a}$ & 13.5 & 3.12 & .23 & 2.81 & 1.12 & .49 & 126 \\
\hline 4.80 & 2.91 & 8.03 & 26 & .37 & $12.6 \mathrm{ab}$ & 11.3 & 3.08 & .22 & 2.48 & 1.16 & .60 & 150 \\
\hline 4.60 & 4.78 & 6.32 & 42 & .74 & $13.0 \mathrm{ab}$ & 12.1 & 3.11 & .21 & 2.69 & 1.15 & .53 & 196 \\
\hline 4.50 & 6.51 & 5.58 & 53 & 1.11 & $8.9 \mathrm{~b}$ & 7.7 & 2.99 & .24 & 2.61 & 1.02 & .57 & 136 \\
\hline 4.40 & 7.52 & 3.69 & 67 & 2.08 & $9.0 \mathrm{~b}$ & 7.7 & 2.91 & .23 & 2.39 & 1.17 & .57 & 150 \\
\hline 4.20 & 9.59 & 2.05 & 81 & 4.60 & $4.6 \mathrm{c}$ & 6.0 & 2.94 & .22 & 2.52 & 1.02 & .42 & 178 \\
\hline \multicolumn{13}{|c|}{ Coto sandy clay } \\
\hline 6.10 & 0 & 4.71 & 0 & 0 & $5.3 \mathrm{ab}$ & 15.7 & 2.58 & .22 & 3.37 & 1.19 & .43 & 129 \\
\hline 5.00 & .32 & 4.02 & 7 & .07 & $4.8 \mathrm{ab}$ & 17.0 & 2.60 & .20 & 3.17 & 1.26 & .42 & 178 \\
\hline 4.70 & .84 & 3.11 & 20 & .25 & $5.9 \mathrm{a}$ & 20.1 & 2.55 & .21 & 3.13 & 1.13 & .42 & 172 \\
\hline 4.50 & 1.26 & 2.36 & 34 & .46 & $3.6 \mathrm{~b}$ & 15.4 & 2.58 & .21 & 3.40 & 1.21 & .45 & 236 \\
\hline
\end{tabular}

${ }^{1}$ Means followed by one or more letters in common do not differ significantly at the $5 \%$ probability level (Duncan multiple range test). 
about $50 \%$ of the variations observed, percent $\mathrm{Al}$ saturation of the soil CEC explained $45 \%$, and the ratio of exchangeable Al to exchangeable bases, 37\%. The Ca content of the leaves correlated significantly with yields, explaining $38 \%$ of the variations observed.

\section{COROZAL CLAY SUBSOIL}

The effects of soil acidity factors on yields of tubers and corms in the subsoil were similar to those in the Corozal soil (table 1). Leaf composition was not appreciably affected by acidity, except that $\mathrm{Ca}$ content was depressed at the highest level of soil acidity.

TABLE 2.-Relationship between tanier yields and soil acidity factors on two Ultisols and an Oxisol

\begin{tabular}{lcc}
\hline \multicolumn{1}{c}{ Soil acidity factor } & Tuber yields (t/ha) & $\begin{array}{c}\text { Correlation } \\
\text { coefficient } \\
(\mathrm{r})\end{array}$ \\
\hline pH & Corozal clay-soil & \\
Percent Al saturation & $\mathrm{Y}=-147.7+57.0 \mathrm{X}-4.9 \mathrm{X}^{2}$ & $.66^{* 1}$ \\
Exch. Al/Exch. bases & $\mathrm{Y}=16.2-.14 \mathrm{X}$ & $.67^{*}$ \\
Exch. Ca $+\mathrm{Mg}$ & $\mathrm{Y}=1.96 \times 1.17 \mathrm{X}$ & $.61^{*}$ \\
Ca content of leaves & $(\mathrm{X})$ vs. yield $(\mathrm{Y})=-19.0+24.9 \mathrm{X}$ & $.72^{*}$ \\
& Corozal clay-subsoil & $.62^{*}$ \\
pH & $\mathrm{Y}=42.3+11.3 \mathrm{X}$ & $.76^{*}$ \\
Percent Al saturation & $\mathrm{Y}=16.9-.13 \mathrm{X}$ & $.71^{*}$ \\
Exch. Al/Exch. bases & $\mathrm{Y}=14.2-2.17 \mathrm{X}$ & $.71^{*}$ \\
Exch. Ca $+\mathrm{Mg}$ & $\mathrm{Y}=.42+2.55 \mathrm{X}-.106 \mathrm{X}^{2}$ & $.71^{*}$ \\
Ca content of leaves & $(\mathrm{X})$ vs yield $(\mathrm{Y})=-10.05+18.3 \mathrm{X}$ & $.52^{*}$ \\
& Coto sandy clay & $.44^{*}$ \\
pH & $\mathrm{Y}=19.27+8.95 \mathrm{X}-.76 \mathrm{X}^{2}$ & $.35^{*}$ \\
Percent Al saturation & $\mathrm{Y}=6.8-.04 \mathrm{X}$ & $.36^{*}$ \\
Exch. Al/Exch. bases & $\mathrm{Y}=6.8-2.95 \mathrm{X}$ & $.37^{*}$ \\
Exch. Ca + Mg & $\mathrm{Y}=.77+2.88 \mathrm{X}-.34 \mathrm{X}^{2}$ & \\
Ca content of leaves & $(\mathrm{X})$ vs yield $(\mathrm{Y})=$ not significant & \\
\hline
\end{tabular}

${ }^{1}$ Significant at least at .05 level.

Table 2 shows that all soil acidity factors correlated with yields at the .01 level. Soil pH explained about $58 \%$ of the variation in tuber yields. Percent $\mathrm{Al}$ saturation of the soil $\mathrm{CEC}$, exchangeable $\mathrm{Ca}+\mathrm{Mg}$, and the ratio of exchangeable $\mathrm{Al}$ to exchangeable bases explained about $50 \%$ of the variations in yield. Calcium content of the leaves correlated with yields, but explained only about $27 \%$ of the observed variations.

\section{COTO SANDY CLAY}

The yield of tubers was very low and was depressed further only by the highest level of acidity, $\mathrm{pH} 4.5$, and $35 \% \mathrm{Al}$ saturation of the soil 
CEC (table 1). Yield of corms was almost as high as that obtained on Corozal soil and was not affected by soil acidity. Soil acidity did not affect foliar composition appreciably.

Tuber yields correlated weakly with soil acidity factors (table 2), and did not correlate with the Ca content of the leaves.

\section{ALL SOILS COMBINED}

Regression analysis of the combined data for the three soils (fig. 1 and 2) showed that either $\mathrm{pH}$ or percent $\mathrm{Al}$ saturation of the soil $\mathrm{CEC}$ explained more than $80 \%$ of the variations observed in tuber yields.

Yields of tubers were close to maximum when the soil $\mathrm{pH}$ was around

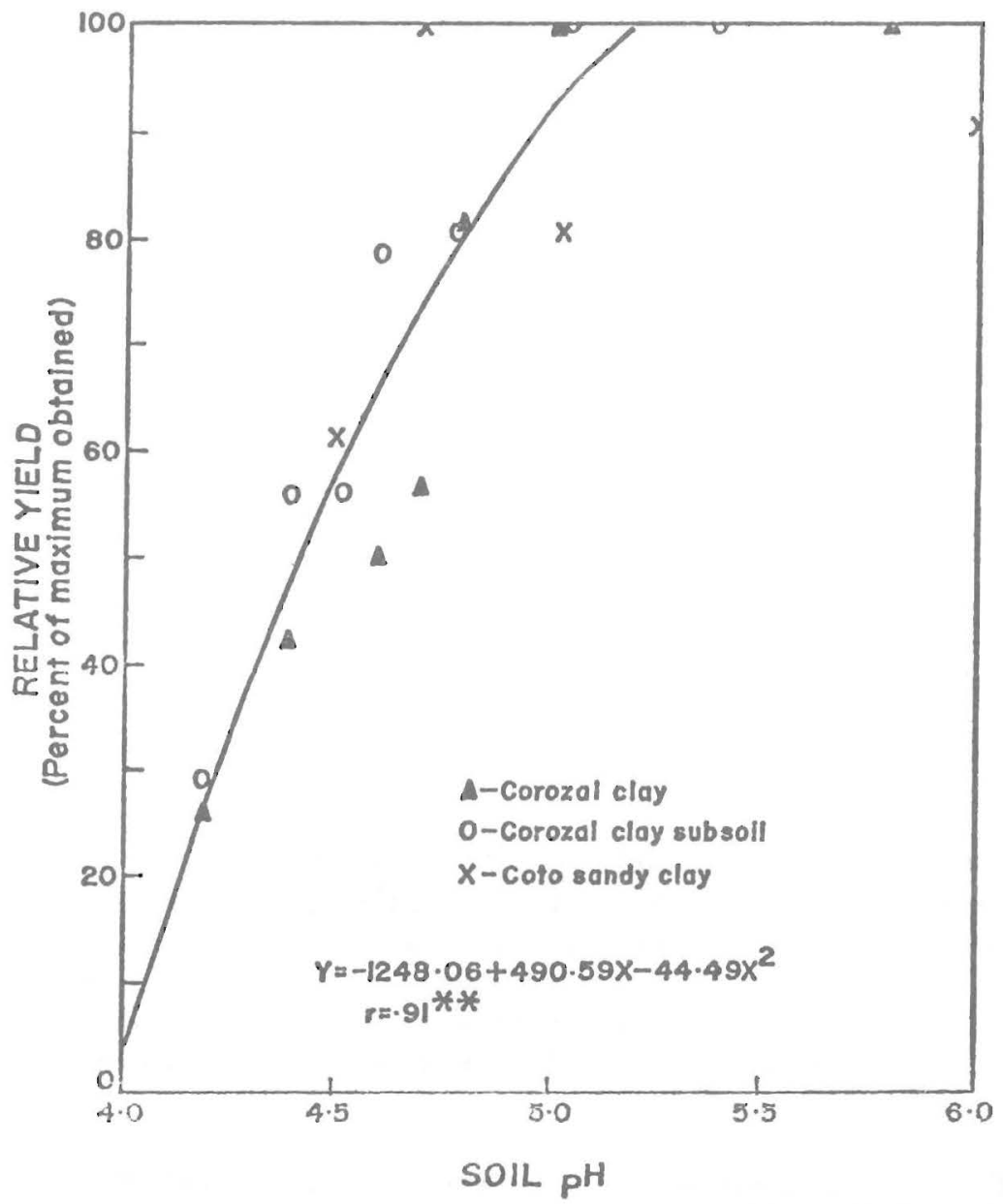

FIG. 1.-Relationship between $\mathrm{pH}$ of two Ultisols and one Oxisol and tuber yield of tanier. 


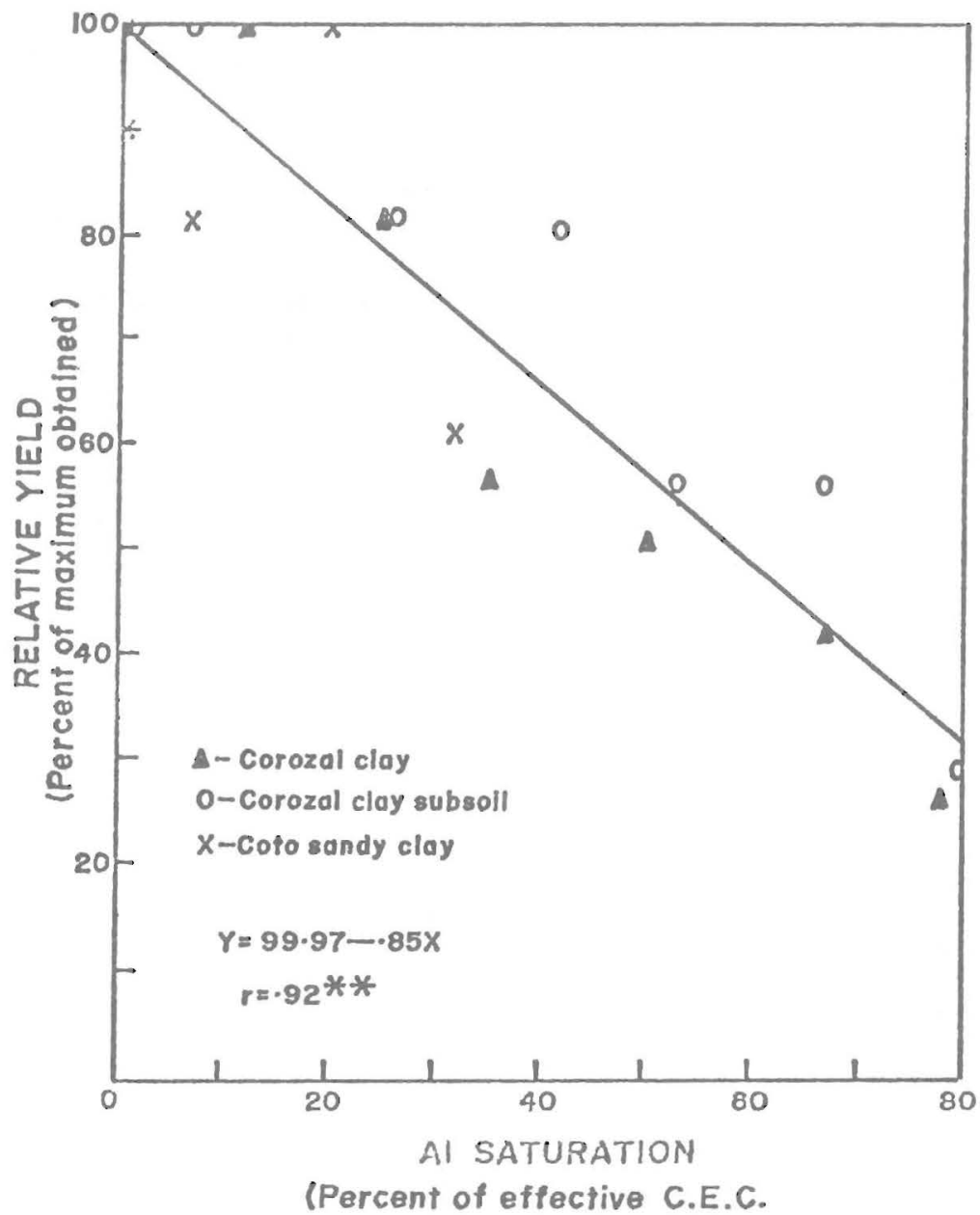

FIG. 2.-Relationship between percent Al saturation of the effective cation exchange capacity of two Ultisols and one Oxisol and tuber yield of tanier

5.2 with no exchangeable $\mathrm{Al}$ in the soil, but only about $50 \%$ of maximum yields when the soil $\mathrm{pH}$ was about 4.5 and $\mathrm{Al}$ saturation of the soil CEC was $60 \%$, a level common in Ultisols.

\section{RESUMEN}

Se estudió el efecto de los factores de acidez del suelo en la producción y composición foliar de la yautía en dos Ultisol en Corozal y un Oxisol en Isabela. En el suelo Corozal la producción de tubérculos disminuyó cuando el pH del suelo bajó de 4.8, lo que correspondió a $25 \%$ de saturación de la capacidad de cambio del suelo con aluminio. Cuando el $\mathrm{pH}$ del suelo bajó a 4.2 , que corresponde a un $78 \%$ de saturación de la capacidad de 
cambio del suelo con aluminio, la producción fue de solamente un $25 \%$ del máximo. La producción de "madres" (cormos) siguió un patrón similar al de los "hijos".

El efecto de los factores de acidez en la producción de la yautía creciendo en subsuelo Corozal fue similar a la que creció en el suelo.

En el suelo Coto, la producción de hijos fue mucho más baja que en el Corozal y disminuyó solamente cuando la acidez bajó a pH 4.5, lo que corresponde a $34 \%$ de saturación de la capacidad de cambio con aluminio. La producción de "madres" fue casi tan alta en el suelo Coto como en el Corozal, sin afectar la acidez.

Los rendimientos más altos se obtuvieron cuando el $\mathrm{pH}$ del suelo fue de 5.2 o más, a cuya acidez no hay aluminio cambiable en el suelo. A $60 \%$ de saturación de los suelos con aluminio, equivalente a $\mathrm{pH} 4.5$, el rendimiento fue alrededor del 50\% del máximo.

\section{LITERATURE CITED}

1. Abruña, F., Boneta, E., Vicente-Chandler, J. and Silva, S., 1967. Experiments on taniers with conservation in Puerto Rico's mountain region, J. Agric. Univ. P.R. 51 (2) $167-$ 75.

2. — Vicente-Chandler, J., Rivera, E. and Rodriguez, J., 1982. Effect of soil acidity factor on yield and foliar composition of tropical root crops, Soil Sci. J. (in press)

3. _ Vicente-Chandler, J., Rodriguez, J., Bonilla, J. and Silva, S., 1979. Crop response to soil acidity factors in Ultisols and Oxisols in Puerto Rico. V. Sweet potato, J. Agric. Univ. P.R. 63 (2) 250-67.

4. Chang, K. L. and Bray, R. H., 1951. Determination of calcium and magnesium in soil and plant material, Soil Sci. 72: 5 449-58.

5. Coleman, N. T., Weed, S. B. and McCraken, R. J., 1959. Cation exchange capacity and exchangeable cations in Piedmont soils of North Carolina, Soil Sci. Soc. Am. Proc. 23: $146-49$.

6. Irizarry, H., Badillo, J. and Rivera, J. R., 1976. Effect of time of planting and age of harvest on marketable yield and quality of four tanier cultivars, J. Agric. Univ. P.R. 60 (3) $253-61$.

7. John, M. K., 1970. Colorimetric determination of phosphorus in soil and plant materials with ascorbic acid, Soil Sci. 109 (4) 214-20.

8. McLean, E. O., 1965. Aluminum: In Methods of soil analyses. Am. Soc. Agron. Agron. Series 9: 994-96.

9. Rodriguez-Garcia, J., Abruña, F. and Diaz, N., 1981. Effect on tanier yields of artificial shade levels and of intercropping with plantains, J. Agric. Univ. P.R. 65 (4) 326-30.

10. Silva, S. and Irizarry, H., 1980. Effect of depth of water table on yield of taniers, $J$. Agric. Univ. P.R. 64 (2) 241-42.

11. Soldevila, M. and Vicente-Chandler, J., 1978. Tanier corms as feed for growing pigs, J. Agric. Univ. P.R. 62 (3) 283-89.

12. Vicente-Chandler, J., Abruña, F. and Silva, S., 1966. Effect of shade trees on yields of five crops in the humid mountain region of Puerto Rico, J. Agric. Univ. P.R. 50 (3) 218-25.

13. — Irizarry, H. and Silva, S., 1982. Nutrient uptake by taniers as related to stage of growth and effect of age on yields of the Morada variety, J. Agric. Univ. P.R. 66 (1) 1-10. 